\title{
AMPH-IMA04: a revised Hypercard program to determine the name of an amphibole from chemical analyses according to the 2004 International Mineralogical Association scheme
}

\author{
A. Mogessie ${ }^{1} *$, K. Ettinger ${ }^{1}$ And B. E. Leake ${ }^{2}$ \\ ${ }^{1}$ Institute of Mineralogy and Petrology, University of Graz, Universitaetsplatz 2, A-8010 Austria \\ ${ }^{2}$ School of Earth, Ocean and Planetary Sciences, Cardiff University, P.O.Box 914 Cardiff CF1 3YE, UK
}

\section{ABSTRACT}

In 2004, the International Mineralogical Association (IMA) amended the IMA 97 amphibole classification and nomenclature scheme by adding a fifth group to include the recently discovered ${ }^{B}(\mathrm{LiNa})$ amphiboles ferriwhittakeriite and ferri-ottoliniite, which cannot be fitted into the four major amphibole groups. New root-names such as sodic-pedrizite in the Mg-Fe-Mn-Li group and obertiite and dellaventuraite in the sodic group along with two new prefixes, parvo and magno have also been added. As result it has become necessary to modify the AMPH-IMA97 amphibole-naming program. The new program (AMPH-IMA04) allows single input or automatic input of as many amphibole analyses as are available following a set input format. Any of three different calculation schemes for dealing with an amphibole analysis can be chosen: (1) complete chemical analyses can be calculated to $24(\mathrm{O}, \mathrm{OH}, \mathrm{F}, \mathrm{Cl})$; (2) analyses with determined $\mathrm{FeO}$ and $\mathrm{Fe}_{2} \mathrm{O}_{3}, \mathrm{MnO}$ and $\mathrm{Mn}_{2} \mathrm{O}_{3}$ but without $\mathrm{H}_{2} \mathrm{O}$ can be calculated to 23(O); and (3) electron microprobe analyses with only total Fe determined and without $\mathrm{H}_{2} \mathrm{O}$ can be calculated to 23(O) with IMA97-recommended normalization for $\mathrm{Fe}^{3+}$ and $\mathrm{Fe}^{2+}$ values. In addition a stoichiometric calculation of $\mathrm{Mn}^{2+}$ and $\mathrm{Mn}^{3+}$ is considered and implemented for the Mn-bearing sodic amphiboles in order to take care of electron microprobe analyses of such amphiboles where the total $\mathrm{Mn}$ is given as $\mathrm{Mn}^{2+}$.

KEYwoRDs: Hypercard, amphibole classification, amphibole-naming, IMA-nomenclature.

\section{Introduction}

SINCE the first ever internationally agreed amphibole nomenclature (IMA78) was approved by the International Mineralogical Association (IMA), several computer programs have been written to classify and name amphiboles based solely upon the chemistry and crystal symmetry (orthorhombic or monoclinic). They include programs by Mogessie and Tessadri (1982), Rock and Leake (1984), Rock (1987), Gobel and Smith (1988), Mogessie et al. (1990), Richard and Clarke (1990), Currie (1991, 1997), Tindle

\footnotetext{
* E-mail: aberra.mogessie@uni-graz.at
}

DOI: $10.1180 / 0026461046850223$ and Webb (1994), Yavuz (1996, 1999) and Mogessie et al. (2001).

More recently (Leake et al., 2004), the IMA revised the 1997 amphibole nomenclature scheme, mainly in order to include recently discovered ${ }^{B}(\mathrm{LiNa})$ amphiboles which necessitated defining a new fifth amphibole group (Na-Ca-Mg-Fe-Mn-Li) but also to include other newly discovered species in the sodic and $\mathrm{Mg}$-Fe-Mn-Li groups.

The newly discovered amphiboles which were not described in 1997 and are included in the revised IMA04 scheme (Leake et al., 2004), are sodic-ferripedrizite, $\mathrm{NaLi}_{2}\left(\mathrm{Mg}_{2} \mathrm{Fe}_{2}^{3+} \mathrm{Li}\right)$ $\mathrm{Si}_{8} \mathrm{O}_{22}(\mathrm{OH})_{2}$, (Oberti et al., 2000), sodic-ferriferropedrizite, $\mathrm{NaLi}_{2}\left(\mathrm{Fe}_{2}^{2+} \mathrm{Fe}_{2}^{3+} \mathrm{Li}\right) \mathrm{Si}_{8} \mathrm{O}_{22}(\mathrm{OH})_{2}$ (Oberti et al., 2004), ferri-ottoloniite, $\square \mathrm{NaLi}\left(\mathrm{Mg}_{3} \mathrm{Fe}^{3+} \mathrm{Li}\right) \mathrm{Si}_{8} \mathrm{O}_{22}(\mathrm{OH})_{2}$ (Oberti et al., 2004), ferriwhittakerite, $\mathrm{Na}(\mathrm{NaLi})\left(\mathrm{Mg}_{2} \mathrm{Fe}_{2}^{3+} \mathrm{Li}\right)$ 
$\mathrm{Si}_{8} \mathrm{O}_{22}(\mathrm{OH})_{2}$ (Oberti et al., 2004), obertiite $\mathrm{NaNa}_{2}\left(\mathrm{Mg}_{3} \mathrm{Fe}^{3+} \mathrm{Ti}\right) \mathrm{Si}_{8} \mathrm{O}_{22} \mathrm{O}_{2}$ (Hawthorne et al., 2002) and dellaventuraite $\mathrm{NaNa}_{2}\left(\mathrm{MgMn}_{2}^{3+} \mathrm{TiLi}\right)$ $\mathrm{Si}_{8} \mathrm{O}_{22} \mathrm{O}_{2}$. It should be noted that the name given to the ferripedrizite by Caballero et al. (2002), was changed to sodic-ferripedrizite in Leake et al. (2004), which may have caused confusion. The present scheme has five more root names than IMA97 and two new prefixes, as described below. Chemistry and crystal symmetry still control nomenclature (Leake et al., 2004).

\section{IMA04 amphibole classification}

The standard amphibole formula unit of $A_{0-1} B_{2} C_{5} T_{8} \mathrm{O}_{22}(\mathrm{OH})_{2}$ is the basis of the classification. The allocation of ions to positions is as follows:

(1) Sum $T$ to 8 using $\mathrm{Si}$, then $\mathrm{Al}$, then $\mathrm{Ti}$.

(2) Sum $C$ to 5 using excess Al, then excess Ti from (1) and then successively, $\mathrm{Fe}^{3+}, \mathrm{V}, \mathrm{Cr}, \mathrm{Mn}^{3+}$, $\mathrm{Zr}, \mathrm{Mg}, \mathrm{Zn}, \mathrm{Ni}, \mathrm{Co}, \mathrm{Fe}^{2+}, \mathrm{Mn}^{2+}$, Li.

(3) Sum $B$ to 2 using first any excess above 5.00 from $\mathrm{C}$, in the reverse order of (2) starting with $\mathrm{Li}$ and then $\mathrm{Mn}^{2+}$ etc., and then follow with $\mathrm{Ca}, \mathrm{Sr}$, $\mathrm{Ba}$ and $\mathrm{Na}$.

(4) Excess above 2.00 in $B$ is assigned to $A$ in the reverse order of (3), starting with $\mathrm{Na}$ and then finally all the $\mathrm{K}$ is allocated to $A$. Total $A$ should be 0 to 1.00 .

If the $\mathrm{H}_{2} \mathrm{O}$ and halogen contents are well established, the formula should be calculated to $24(\mathrm{O}, \mathrm{OH}, \mathrm{F}, \mathrm{Cl})$, but if these are uncertain, the formula should be calculated to $23(\mathrm{O})$ with $2(\mathrm{OH}, \mathrm{F}, \mathrm{Cl})$ assumed, unless this leads to an impossibility of satisfying any of the following criteria, in which instance an appropriate change in the number of $(\mathrm{OH}+\mathrm{F}+\mathrm{Cl})$ should be made. This last point is considered in the AMPH-IMA04 program for sodic amphiboles which are anhydrous or with $(\mathrm{OH}+\mathrm{F}+\mathrm{Cl})<1$, such as obertiite, ungarettiite $\mathrm{NaNa}_{2}\left(\mathrm{Mn}_{2}^{2+} \mathrm{Mn}_{3}^{3+}\right) \mathrm{Si}_{8} \mathrm{O}_{22} \mathrm{O}_{2}$, and dellaventuraite, and the calcic amphibole, kaersutite, $\mathrm{NaCa}_{2}\left(\mathrm{Mg}_{4} \mathrm{Ti}\right) \mathrm{Si}_{6} \mathrm{Al}_{2} \mathrm{O}_{23}(\mathrm{OH})$, where the total oxygen is taken as 23.5 and $(\mathrm{OH}, \mathrm{F}, \mathrm{Cl})=1$ (see calculated analysis of kaersutite in Table 1).

Before Leake et al. (2004), the amphiboles were primarily classified into 4 major groups: Group I - Mg-Fe-Mn-Li amphiboles; Group II calcic amphiboles; Group III - sodic-calcic amphiboles; and Group IV - sodic amphiboles. Now the amphiboles are classified primarily into five groups, still based on occupancy of the $B$ positions.
Group 1. Where the sum of the L-type ions ${ }^{B}\left(\mathrm{Mg}+\mathrm{Fe}^{2+}+\mathrm{Mn}^{2+}+\mathrm{Li}\right) \geqslant 1.50$, then the amphibole belongs to the $\mathrm{Mg}-\mathrm{Fe}-\mathrm{Mn}-\mathrm{Li}$ group.

Group 2. Where ${ }^{B}\left(\mathrm{Mg}+\mathrm{Fe}^{2+}+\mathrm{Mn}^{2+}+\mathrm{Li}\right) \leqslant 0.50$, ${ }^{B}(\mathrm{Ca}+\mathrm{Na}) \geqslant 1.00$ and ${ }^{B} \mathrm{Na}<0.50$, then the amphibole is a member of the calcic group.

Group 3. Where ${ }^{B}\left(\mathrm{Mg}+\mathrm{Fe}^{2+}+\mathrm{Mn}^{2+}+\mathrm{Li}\right) \leqslant 0.50$, ${ }^{B}(\mathrm{Ca}+\mathrm{Na}) \geqslant 1.00$ and $0.50 \leqslant{ }^{B} \mathrm{Na}<1.50$ then the amphibole is a member of the sodic-calcic group. Group 4. Where ${ }^{B}\left(\mathrm{Mg}+\mathrm{Fe}^{2+}+\mathrm{Mn}^{2+}+\mathrm{Li}\right) \leqslant 0.50$, ${ }^{B} \mathrm{Na} \geqslant 1.50$, then the amphibole is a member of the sodic group.

Group 5. Where $0.5<{ }^{B}\left(\mathrm{Mg}+\mathrm{Fe}^{2+}+\mathrm{Mn}^{2+}+\mathrm{Li}\right)$ $<1.50,0.50 \leqslant{ }^{B}(\mathrm{Ca}+\mathrm{Na}) \leqslant 1.50$, then the amphibole is a member of the sodic-calcic-MgFe-Mn-Li group.

Root names are envisaged based on charge arrangements and crystal symmetry. Prefixes (given in IMA97 and IMA04) indicate additional major substitutions while optional modifiers (listed in IMA97) specify less important substitutions. The new major amphibole Group 5 was established to give identity to the new ${ }^{B}(\mathrm{LiNa})$ amphiboles ferri-ottoliniite and ferriwhittakerite but a few Li-poor compositions also fall into this new group, and because IMA did not wish to see the already large number (34) of root names increased unless unavoidably, Group 5 Li-poor (defined as ${ }^{B} \mathrm{Li} \leqslant 0.50$ ) compositions retain the same root names that they had before Group 5 was established. Such compositions acquire one of two new prefixes, restricted in use to Group 5, parvo if they would have been calcic or sodiccalcic amphiboles and magno if they would have been $\mathrm{Mg}-\mathrm{Fe}-\mathrm{Mn}-\mathrm{Li}$ amphiboles (Leake et al., 2004). Because of chemical overlaps between some of the orthorhombic and monoclinic members of the Mg-Fe-Mn-Li group, two names are output, (e.g. anthophyllite and cummingtonite) and the crystal symmetry has to be known to decide the correct name.

\section{Problems with IMA04}

It is difficult to assign the correct name to an amphibole analysed with the electron microprobe, since it is difficult to know how much of the analysed $\mathrm{Fe}$ is $\mathrm{FeO}$ or $\mathrm{Fe}_{2} \mathrm{O}_{3}$, i.e. $\mathrm{Fe}^{2+}$ and $\mathrm{Fe}^{3+}$. A detailed discussion of the stoichiometric calculation of $\mathrm{Fe}^{2+}$ and $\mathrm{Fe}^{3+}$ from electron microprobe analyses is given by Mogessie et al. (2001) and will not be repeated here. For sodic amphiboles such as kornite, $(\mathrm{Na}, \mathrm{K}) \mathrm{Na}_{2}\left(\mathrm{Mg}_{2} \mathrm{Mn}_{2}^{3+} \mathrm{Li}\right) \mathrm{Si}_{8} \mathrm{O}_{22}(\mathrm{OH})_{2}$, leakeite, 
TABLE 1. An edited excel table for calculated amphiboles imported using the 'file' background icon. Original names are given in the first row and the calculated names using AMPH-IMA04 in the last row.

\begin{tabular}{|c|c|c|c|c|c|c|c|}
\hline Sample & Obertiite & Kozulite & Leakeite & Kaersutite & Whittakerite & Ottoliniite & Sodic-ferripedrizite \\
\hline $\mathrm{SiO}_{2}$ & 56.27 & 50.32 & 56.76 & 42.13 & 59.94 & 60.36 & 58.99 \\
\hline $\mathrm{TiO}_{2}$ & 9.35 & & & 9.33 & & & \\
\hline $\mathrm{Al}_{2} \mathrm{O}_{3}$ & & & & 11.92 & 6.36 & 6.4 & \\
\hline $\mathrm{Mn}_{2} \mathrm{O}_{3}$ & & & & & & & \\
\hline $\mathrm{Fe}_{2} \mathrm{O}_{3}$ & & & & & & & \\
\hline $\mathrm{MgO}$ & 14.15 & & 9.52 & 18.84 & 10.05 & 15.18 & 9.89 \\
\hline $\mathrm{MnO}$ & & 29.7 & & & & & \\
\hline $\mathrm{FeO}$ & 8.41 & 7.52 & 16.97 & & 8.96 & 9.02 & 17.64 \\
\hline $\mathrm{CaO}$ & & & & 13.11 & & & \\
\hline $\mathrm{Li}_{2} \mathrm{O}$ & & & 1.76 & & 3.73 & 1.88 & 5.5 \\
\hline $\mathrm{Na}_{2} \mathrm{O}$ & 10.88 & 9.73 & 10.98 & 3.62 & 7.73 & 3.89 & 3.8 \\
\hline $\mathrm{K}_{2} \mathrm{O}$ & & & & & & & \\
\hline Total & 99.06 & 97.27 & 95.99 & 98.95 & 96.77 & 96.73 & 95.82 \\
\hline$-\mathrm{O}=\mathrm{F}, \mathrm{Cl}$ & 0 & 0 & 0 & 0 & 0 & 0 & 0 \\
\hline Total & 99.06 & 97.27 & 95.99 & 98.95 & 96.77 & 96.73 & 95.82 \\
\hline $\mathrm{H}_{2} \mathrm{O}$ calc. & & 1.886 & 2.127 & 2.105 & 2.247 & 2.262 & 2.211 \\
\hline $\mathrm{Si}$ & 8 & 8 & 8 & 6 & 7.999 & 8 & 8 \\
\hline $\mathrm{Al}$ & 0 & 0 & 0 & 2 & 0.001 & 0 & 0 \\
\hline $\mathrm{Ti}$ & 0 & 0 & 0 & 0 & 0 & 0 & 0 \\
\hline sum $\mathrm{T}$ & 8 & 8 & 8 & 8 & 8 & 8 & 8 \\
\hline $\mathrm{Al}$ & 0 & 0 & 0 & 0.001 & 0.999 & 1 & 0 \\
\hline $\mathrm{Ti}$ & 1 & 0 & 0 & 0.999 & 0 & 0 & 0 \\
\hline $\mathrm{Fe}^{3+}$ & 1 & 1 & 2 & 0 & 1 & 1 & 2.001 \\
\hline $\mathrm{Mn}^{3+}$ & 0 & 0.003 & 0 & 0 & 0 & 0 & 0 \\
\hline Mg & 2.999 & 0 & 2 & 4 & 1.999 & 2.999 & 1.999 \\
\hline $\mathrm{Fe}^{2+}$ & 0 & 0 & 0 & 0 & 0 & 0 & 0 \\
\hline $\mathrm{Mn}^{2+}$ & 0 & 3.996 & 0 & 0 & 0 & 0 & 0 \\
\hline $\mathrm{Li}$ & 0 & 0 & 0.998 & 0 & 1.002 & 0.001 & 1 \\
\hline sum $\mathrm{C}$ & 4.999 & 4.999 & 4.998 & 5 & 5 & 5 & 5 \\
\hline $\mathrm{Mg}$ & 0 & 0 & 0 & 0 & 0 & 0 & 0 \\
\hline $\mathrm{Fe}^{2+}$ & 0 & 0 & 0 & 0 & 0 & 0 & 0 \\
\hline $\mathrm{Mn}^{2+}$ & 0 & 0 & 0 & 0 & 0 & 0 & 0 \\
\hline $\mathrm{Li}$ & 0 & 0 & 0 & 0 & 1 & 1.001 & 2 \\
\hline $\mathrm{Ca}$ & 0 & 0 & 0 & 2 & 0 & 0 & 0 \\
\hline $\mathrm{Na}$ & 2 & 2 & 2 & 0 & 1 & 0.999 & 0 \\
\hline sum B & 2 & 2 & 2 & 2 & 2 & 2 & 2 \\
\hline $\mathrm{Ca}$ & 0 & 0 & 0 & 0 & 0 & 0 & 0 \\
\hline $\mathrm{Na}$ & 0.999 & 0.999 & 1 & 1 & 1 & 0.001 & 0.999 \\
\hline K & 0 & 0 & 0 & 0 & 0 & 0 & 0 \\
\hline sum A & 0.999 & 0.999 & 1 & 1 & 1 & 0.001 & 0.999 \\
\hline catsum & 15.998 & 15.999 & 15.998 & 15.999 & 16 & 15 & 15.999 \\
\hline $\mathrm{OH}$ & 0 & 2 & 2 & 0 & 2 & 2 & 2 \\
\hline Oxeq & 24 & 23 & 23 & 23.5 & 23 & 23 & 23 \\
\hline
\end{tabular}

AMPH- Obertiite Kozulite Leakeite Kaersutite Whittakerite Ottoliniite Sodic-ferripedrizite IMA04 
$\mathrm{NaNa}_{2}\left(\mathrm{Mg}_{2} \mathrm{Fe}_{2}^{3+} \mathrm{Li}\right) \mathrm{Si}_{8} \mathrm{O}_{22}(\mathrm{OH})_{2}$ ungarettiite and dellaventuraite, the $\mathrm{Mn}^{3+}$ content is important for classification and nomenclature. However, most amphiboles are analysed with the electron microprobe and similar to the problem we have with $\mathrm{Fe}$ it is difficult to determine how much of the analysed $\mathrm{Mn}$ is $\mathrm{MnO}$ or $\mathrm{Mn}_{2} \mathrm{O}_{3}$, i.e. $\mathrm{Mn}^{2+}$ and $\mathrm{Mn}^{3+}$. Therefore, for such types of amphiboles it is important to calculate the $\mathrm{Mn}^{2+}$ and $\mathrm{Mn}^{3+}$ from the electron microprobe data using stoichiometric methods as employed to determine $\mathrm{Fe}^{2+}$ and $\mathrm{Fe}^{3+}$ (Stout, 1972; Droop, 1987; Schumacher, 1991, 1997). We have attempted to make a stoichiometric calculation for $\mathrm{Mn}^{2+}$ and $\mathrm{Mn}^{3+}$ after the calculation has been made to distribute $\mathrm{Fe}$ into $\mathrm{Fe}^{2+}$ and $\mathrm{Fe}^{3+}$ and the total calculated oxygen is found to be $<23$ or the charge balance is $<48$ when calculated to 24 oxygens. As far as we know this is the first time that an attempt has been made to calculate the $\mathrm{Mn}^{2+}$ and $\mathrm{Mn}^{3+}$ in addition to $\mathrm{Fe}^{2+}$ and $\mathrm{Fe}^{3+}$ from a microprobe analysis in order to take care of the $\mathrm{Mn}^{3+}$-rich sodic amphiboles.

\section{Discussion}

Compared with the previous AMPH-IMA97 program (Mogessie et al., 2001), the new program extends the elements to include $\mathrm{V}, \mathrm{Co}$, $\mathrm{Ni}, \mathrm{Zr}, \mathrm{Sr}$ and $\mathrm{Ba}$. There are three options for each analysis in the new program (Fig. 1) with some modifications to those stated in Mogessie et al. (2001). The three options are:

(1) Complete $\left(\mathrm{FeO}, \mathrm{Fe}_{2} \mathrm{O}_{3}, \mathrm{H}_{2} \mathrm{O}\right)$ chemical analyses can be calculated to $24(\mathrm{O}, \mathrm{OH}, \mathrm{F}, \mathrm{Cl})$.

Analyses with zero $\mathrm{Fe}_{2} \mathrm{O}_{3}$ and $\mathrm{Mn}_{2} \mathrm{O}_{3}$ are automatically calculated using 23(O) and the $\mathrm{FeO}_{\text {total }}$ normalized.

(2) Analyses with determined $\mathrm{FeO}, \mathrm{Fe}_{2} \mathrm{O}_{3}$, $\mathrm{MnO}$ and/or $\mathrm{Mn}_{2} \mathrm{O}_{3}$ but not $\mathrm{H}_{2} \mathrm{O}$, can be calculated to $23(\mathrm{O})$.

(3) Analyses without determined $\mathrm{FeO}, \mathrm{Fe}_{2} \mathrm{O}_{3}$, $\mathrm{MnO}, \mathrm{Mn}_{2} \mathrm{O}_{3}$ and $\mathrm{H}_{2} \mathrm{O}$, but with determined total $\mathrm{Fe}$ and $\mathrm{Mn}$ can be calculated to $23(\mathrm{O})$ with a normalization scheme.

It is important to note that the Mn-normalization is made only for sodic amphiboles where

\begin{tabular}{|c|c|c|c|c|c|c|c|c|}
\hline & wt\% & & cations & $\begin{aligned} \text { SAMPLE } \\
\text { Unoarettiite, EM }\end{aligned}$ & \multirow{2}{*}{\multicolumn{4}{|c|}{$\begin{array}{l}\text { AMPH-IMA } 2004 \\
\text { A. Mogessie, K. Ettinger \& B.E. Leake }\end{array}$}} \\
\hline $\mathrm{SiO} 2$ & 50.47 & Si & 8.000 & \multirow[t]{3}{*}{ Ungarettiite, EM } & & & & \\
\hline TiO2 & & $\mathrm{Ti}$ & 0.000 & & \multicolumn{2}{|c|}{$\mathrm{T}$} & \multicolumn{2}{|c|}{ Card5 of 21 } \\
\hline ZrO2 & & $\mathrm{Zr}$ & .0.000. & & 8.000 & C & \multirow{2}{*}{\multicolumn{2}{|c|}{$\begin{array}{r}\square \text { mark card } \\
\text { marked } 0\end{array}$}} \\
\hline $\mathrm{Al} 203$ & & Al & 0.000 & calculation scheme & 0.000 & 0.000 & & \\
\hline V203 & & $\mathbf{v}$ & 0.000 & 24 anions or $23(0)$-normalised & 0.000 & 0.000 & & \\
\hline Cr203 & & $\mathrm{Cr}$ & 0.000 & $23(0)$ without normalisation & 8.000 & & & \\
\hline $\mathrm{Mn} 203$ & & $\mathrm{Mn3}+$ & 2998 & $\mathrm{O} 23(0)-\mathrm{Fe} 2 \mathrm{O} 3$ as $\mathrm{FeO}, \mathrm{Mn} 2 \mathrm{O} 3$ as $\mathrm{MnO}$ & $\begin{aligned} \mathrm{Fe} 3+ \\
\mathrm{V}\end{aligned}$ & $\begin{aligned} 0.000 \\
0.000\end{aligned}$ & & \\
\hline $\begin{array}{l}\mathrm{Fe} 2 \mathrm{O} 3 \\
\mathrm{MgO}\end{array}$ & & $\begin{array}{r}\mathrm{Fe} 3+ \\
\mathrm{Mg}\end{array}$ & $\begin{aligned} 0.000 \\
0.000\end{aligned}$ & $\begin{array}{lll}\mathrm{Fe} 2 \mathrm{O} 3 \mathrm{calc} \quad 0.000 & \text { normalised }\end{array}$ & & 0.000 & & \\
\hline Mno & 37.25 & $\mathrm{Mn}$ & 2.003 & $\mathrm{FeO}$ calc & $\begin{aligned} M n 3+ \\
\mathrm{Zr}\end{aligned}$ & $\begin{array}{l}2.998 \\
0.000\end{array}$ & $\frac{B}{0.000}$ & \\
\hline $\mathrm{FeO}$ & & $\mathrm{Fe}$ & 0.000 & & $\mathrm{Mg}$ & 0.000 & 0.000 & \\
\hline $\mathrm{NiO}$ & & $\mathrm{Ni}$ & 0.000 & & $\mathrm{Zn}$ & 0.000 & 0.000 & \\
\hline $\mathrm{CoO}$ & & Co & 0.000 & & $\mathrm{Ni}$ & 0.000 & 0.000 & \\
\hline $\mathrm{ZnO}$ & & $\mathrm{Zn}$ & 0.000 & & Co & 0.000 & 0.000 & \\
\hline $\mathrm{CaO}$ & & $\mathrm{Ca}$ & 0.000 & & $\mathrm{Fe} 2+$ & 0.000 & 0.000 & \\
\hline Sro & & $\mathrm{Sr}$ & 0.000 & classification parameter & $\mathrm{Mn2}+$ & 2.002 & 0.001 & \\
\hline $\mathrm{BaO}$ & & $\mathrm{Ba}$ & 0.000 & 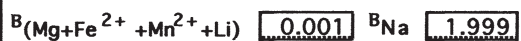 & $\Sigma \mathrm{Li}$ & $\begin{array}{l}0.000 \\
5.000\end{array}$ & 0.000 & A \\
\hline Li20 & & $\mathrm{Li}$ & 0.000 & & & $\mathrm{Ca}$ & 0.000 & 0.000 \\
\hline $\mathrm{Na} 2 \mathrm{O}$ & 9.76 & $\mathrm{Na}$ & 3.000 & ${ }^{A}(\mathrm{Na}+\mathrm{K}) \quad 1.001$ & & $\mathrm{Sr}$ & 0.000 & 0.000 \\
\hline K20 & & K & 0.000 & & & $\mathrm{Ba}$ & 0.000 & 0.000 \\
\hline H2O & & $\Sigma \mathrm{c}$ & 16.001 & $\frac{\mathrm{Mg}}{\mathrm{Mg}+\mathrm{Fe}^{2}}+[0.000]$ & & $\mathrm{Na}$ & 1.999 & 1.001 \\
\hline $\mathbf{F}$ & & $\mathrm{OH}$ & 0.000 & & & & $\frac{2.000}{k}$ & 0.000 \\
\hline $\mathrm{Cl}$ & & $F$ & 0.000 & $\mathrm{Mn}^{2+}+\mathrm{Mn}^{3+} 5.001 \mathrm{~V}^{\mathrm{A}} \mathrm{Al}+\mathrm{Fe}^{3+}+\mathrm{Fe}^{2+}+\mathrm{Mg}$ & 0.000 & & $\Sigma \hat{A}$ & (n) \\
\hline Total & 97.48 & $\mathrm{Cl}$ & 0.000 & Sodic Amphibole, name based on 24 anions & & & & \\
\hline$-\mathrm{O}=\mathrm{F}, \mathrm{Cl}$ & - & $\Sigma a$ & 0.000 & & & & & \\
\hline Total & .97.48. & An, Ox & 24.000 & Ungarettiite & & & & \\
\hline $\mathrm{H} 2 \mathrm{O}$ calc. & & + Charge & 48.000 & & & & & \\
\hline Home file & import & calculat & new & \begin{tabular}{|l|l|l|} 
analysis & delete & sort \\
\end{tabular} & & & & \\
\hline
\end{tabular}

FIG. 1. Output card after calculation of single or multiple amphibole analyses.This is also used as an input card for single or multiple amphibole analyses. 
the concentrations of $\mathrm{Mn}^{2+}$ and $\mathrm{Mn}^{3+}$ are critical for naming the amphibole. We appreciate that the only satisfactory solution to determining Fe and Mn oxidation states is independent Mössbauer, wet chemical or structure refinement methods.

\section{Nomenclature and the problem of $\mathrm{Fe}^{2+}$ and $\mathrm{Fe}^{3+}$ normalization}

In the AMPH-IMA97 (Mogessie et al. 2001) for the normalization options, a $\mathrm{Mg}-\mathrm{Fe}-\mathrm{Mn}-\mathrm{Li}$ group amphibole formula was calculated on the basis of the sum of all the cations, excluding $\mathrm{Na}$ and $\mathrm{K}=$ $15(\Sigma \mathrm{Ca}=15)$, whereas for all the other groups the sum of all the cations, excluding $\mathrm{Ca}, \mathrm{Na}$ and $\mathrm{K}$ $=13(\Sigma F M=13)$ was used. The new amphiboles in Group 5 and $\mathrm{Li}$ - and Mn-bearing sodic amphiboles were calculated using the above assumptions. The result was not satisfactory as there is a continuous chemical composition between Group 5 amphiboles and the rest. Therefore, it became necessary to change this fixed parameter for the normalization procedure and implement the $\mathrm{Fe}^{2+}$ and $\mathrm{Fe}^{3+}$ normalization parameters recommended by Schumacher (1997) which considers the minimum and maximum $\mathrm{Fe}^{3+}$ for a respective amphibole analysis.

The program is set to determine automatically the correct factor that fullfills the stoichiometric criteria and calculates the respective $\mathrm{Fe}^{2+}$ and $\mathrm{Fe}^{3+}$. Apart from this, there were other problems to be considered and solved. These are (1) distribution of $\mathrm{Mn}^{2+}$ and $\mathrm{Mn}^{3+}$ in the sodic amphiboles as discussed above; (2) the calculation of amphibole analyses and nomenclature for sodic amphiboles where $(\mathrm{OH}+\mathrm{F}+\mathrm{Cl})<1$, such as obertiite, ungarettiite and dellaventuraite; and (3) to assign the prefixes 'parvo' and 'magno' to Group 5 amphiboles with ${ }^{B} \mathrm{Li} \leqslant 0.50$ a.p.f.u. (see Table 1). Over 500 amphibole analyses cited in Deer et al. (1997) were calculated and named, proving that the new AMPH-IMA04 program works for all the amphibole groups recommended by Leake et al. (2004).

\section{The AMPH-IMA04 program}

The program is revised to include the recommended new names, the new amphibole group and the additional prefixes 'parvo' and 'magno'. However the description of the program remains the same (Mogessie et al., 2001) only with minor modifications. Compared to the input card for AMPH-IMA97 (Mogessie et al., 2001) the present program has additional elements which include $\mathrm{V}, \mathrm{Co}, \mathrm{Ni}, \mathrm{Zr}, \mathrm{Sr}$ and $\mathrm{Ba}$; and classification parameters $\left({ }^{B}\left(\mathrm{Mg}+\mathrm{Fe}^{2+}+\mathrm{Mn}^{2+}+\right.\right.$ Li), $\left.\left(\mathrm{Mn}^{2+}+\mathrm{Mn}^{3+}\right),\left({ }^{\mathrm{IV}} \mathrm{Al}+\mathrm{Fe}^{3+}+\mathrm{Fe}^{2+}+\mathrm{Mg}\right)\right)$ (Fig. 1). Buttons for 'comments' and 'parageneses' are left out.

It is important to note that one can import as many analyses as necessary using the 'file import' button and automatically calculate the imported data. The data should be in a tab-delimited input format where name, sample or oxides can be arranged in any order but should be in one line per analysis and the respective values must be given in the empty fields following the headings (e.g $\mathrm{SiO}_{2} 50.5$ etc.).

The program AMPH-IMA04 can be downloaded from the Mineralogical Society website: www.minersoc.org/pages/e_journals/ dep_mat.htm

\section{Acknowledgements}

We would like to thank F.C. Hawthorne for giving us permission to use the reference Tait et al. (in press) for the new sodic amphibole dellaventuraite. R. Oberti is thanked for the critical and constructive review of this paper.

\section{References}

Caballero, J.M., Oberti, R. and Ottolini, L. (2002) Ferripedrizite, a new monoclinic ${ }^{\mathrm{B}} \mathrm{Li}$ amphibole endmember from the Eastern Pedriza Massif, Sierra de Guadarrama, Spain, and a restatement of the nomenclature of the $\mathrm{Mg}-\mathrm{Fe}-\mathrm{Mn}-\mathrm{Li}$ amphiboles. American Mineralogist, 87, 976-982.

Currie, K.L. (1991) A simple quantitative calculation of mole fractions of amphibole end-members. The Canadian Mineralogist, 29, 287-299.

Currie, K.L. (1997) A revised computer program for amphibole classification. The Canadian Mineralogist, 35, 1351-1352.

Deer, W.A., Howie, R.A. and Zussman, J. (1997) Rockforming Minerals, vol. 2B. Double-Chain Silicates, $2^{\text {nd }}$ edition. The Geological Society, London, $764 \mathrm{pp}$.

Droop, G.T.R. (1987) A general equation for estimating $\mathrm{Fe}^{3+}$ concentrations in ferromagnesian silicates and oxides from microprobe analyses, using stoichiometeric criteria. Mineralogical Magazine, 51, 431-435.

Gobel, R.J. and Smith, D.G.W. (1988) MinIdent: an application to the identification of amphiboles. Mineralogy and Petrology, 38, 213-227.

Hawthorne, F.C., Cooper, M.A., Grice, J.D. and Ottolini, L. (2002) A new anhydrous amphibole from the Eifel region, Germany: description and crystal structure of 
obertiite, $\mathrm{NaNa}_{2}\left(\mathrm{Mg}_{3} \mathrm{Fe}^{3+} \mathrm{Ti}^{4+}\right) \mathrm{Si}_{8} \mathrm{O}_{22} \mathrm{O}_{2}$. American Mineralogist, 85, 536-541.

Leake, B.E., Woolley, A.R., Birch, W.D., Burke, E.A.J., Ferraris, G., Grice, J.D., Hawthorne, F.C., Kisch, H.J., Krivovichev, V.G., Schumacher, J.C., Stephenson, N.C.N. and Whittaker, E.J.W. (2004) Nomenclature of amphiboles: additions and revisions to the international Mineralogical Association's amphibole nomenclature. Mineralogical Magazine, 68, 209-215.

Mogessie, A. and Tessadri, R. (1982) A BASIC computer program to determine the name of an amphibole from an electron microprobe analysis. Geologische und Palaeontologische Mitteilungen Innsbruck, 11, 259-289.

Mogessie, A., Tessadri, R. and Veltman, C. B. (1990) EMP-AMPH - a hypercard program to determine the name of an amphibole from electron microprobe analysis according to the International Mineralogical Association scheme. Computers \& Geosciences, 16, 309-330.

Mogessie, A., Ettinger, K., Leake, B.E. and Tessadri, R. (2001) AMPH-IMA97: a hypercard program to determine the name of an amphibole from electron microprobe and wet chemical analyses. Computers \& Geosciences, 27, 1169-1178.

Oberti, R., Caballero, J.M., Ottolini, L., Lopez-Andres, S. and Herreros, V. (2000) Sodicferripedrizite, a new monoclinic amphibole bridging the magnesium-ironmanganese-lithium and the sodium-calcic groups. American Mineralogist, 85, 578-585.

Oberti, R., Camara, F. and Caballero, J.M. (2004) Ferriottoliniite and ferriwhittakerite, two end-members in the new Group 5 for amphiboles. American Mineralogist, 89, 888-893.

Richard, L.R. and Clarke, D.B. (1990) AMPHIBOL: a program for calculating structural formulae and for classifying and plotting chemical analyses of amphiboles. American Mineralogist, 75, 421-423.
Rock, N.M.S. (1987) A FORTRAN program for tabulating and naming amphibole analyses according to the International Mineralogical Association Scheme. Mineralogy and Petrology, 37, 79-88.

Rock, N.M.S. and Leake, B.E. (1984) The International Mineralogical Association amphibole nomenclature scheme: computerization and its consquences. Mineralogical Magazine, 48, 211-227.

Schumacher, J.C. (1991) Empirical ferric iron corrections: necessity, assumptions, and effects on selected geothermobarometers. Mineralogical Magazine, 55, $3-18$.

Schumacher, J.C. (1997) Appendix 2: The estimation of ferric iron in electron microprobe analysis of amphiboles. American Mineralogist, 82, 1031-1037.

Stout, J.H. (1972) Phase petrology and mineral chemistry of coexisting amphiboles from Telemark, Norway. Journal of Petrology, 13, 99-145.

Tait, K.T., Hawthorne, F.C., Grice, J.D., Ottolini, L. and Nayak, V.K. (2004) Dellaventuraite $\mathrm{NaNa}_{2}\left(\mathrm{MgMn}^{3+}{ }_{2} \mathrm{Ti}^{4+} \mathrm{Li}^{4}\right) \mathrm{Si}_{8} \mathrm{O}_{22} \mathrm{O}_{2}$ a new anhydrous amphibole from the Kaijlidongri Manganese Mine Jhabua District, Madhya Pradesh, India. The Canadian Mineralogist (in press).

Tindle, A. and Webb, P.C. (1994) PROBE-AMPH: a spreadsheet program to classify microprobe-derived amphibole analyses. Computers \& Geosciences, 20, 1201-1228.

Yavuz, F. (1996) AMPHCAL: a QUICKBASIC program for determining the amphibole name from electron microprobe analyses using the IMA rules. Computers \& Geosciences, 22, 101-107.

Yavuz, F. (1999) A revised program for microprobederived amphibole analyses using the IMA rules. Computers \& Geosciences, 25, 909-927.

[Manuscript received 14 April 2004:

revised 27 August 2004] 